\title{
The Family-Friendly Museum: Museums through the eyes of families
}

\author{
Katalin Ásványi - Zsuzsanna Fehér - Melinda Jászberényi
}

Katalin Ásványi, PhD

Corvinus University of Budapest

Department of Media Marketingcommunications and Designcommunications

8 Fővám Square

1093 Budapest

Hungary

e-mail: katalin.asvanyi@uni-corvinus.hu

Zsuzsanna Fehér

Ludwig Museum

1 Komora Marcell Street

1095 Budapest

Hungary

Corvinus University of Budapest

Tourism Department

8 Fővám Square

1093 Budapest

Hungary

e-mail: feher.zsuzsanna@ludwigmuseum.hu

Melinda Jászberényi, PhD, Habil.

Corvinus University of Budapest

Tourism Department

8 Fővám Square

1093 Budapest

Hungary

e-mail: jaszberenyi@uni-corvinus.hu

\section{The Family-Friendly Museum: Museums through the eyes of families}

According to studies on family leisure time, positive experiences with family members are the most important motivation factor for family leisure activities. In their traditional role, museums are cultural mediators, sources of information and research. However, as the needs of consumers with regards to museums are changing, institutions should instead focus on the opportunity to participate, learn and experience. The aim of our study is to identify key elements that make a museum family friendly and to define criteria for this designation. The framework was constructed based on the analysis of in-depth interviews with families with constructive grounded theory. The study's findings highlight the need for museums to pay attention to families not only during their visit but also in the preparation and follow-up phases. The managerial implications for museums that would like to be family-friendly are discussed and solutions proposed.

Keywords: family visitor, family-friendly museum, museum experience, grounded theory

\section{Introduction}

According to studies on family leisure time, family relationships, especially positive experiences with family members, are the most important motivation factor for family leisure activi- 
ties. ${ }^{1}$ At the same time, researchers also highlight the conflicting finding that one's "own time" is as important as "family time" in family leisure activities. ${ }^{2}$ Time spent with one's family is important for strengthening interpersonal ties and providing opportunities for joint experiences. Then again, one's own time and one's own interests are also important aspects when choosing how to spend free time; for example, parents may wish to break away from everyday life and escape the obligations of family life for a while.

In their traditional role, museums are cultural mediators, sources of information and research $^{3}$. However, as consumers are increasingly demanding products and services that provide a sense of emotion, learning, being, and acting ${ }^{4}$; museums should focus on participation, learning and experiencing instead of the simple act of being. Nowadays, museums are expected to go beyond the functions of collecting, researching and exhibiting, and to engage in experience marketing. This includes providing "fantasy, emotion and fun-driven" experiences, emphasizing symbolic meanings, hedonic experience and subconscious responses rather than focusing on tangible benefits, utilitarian functions and conscious processes ${ }^{5}$. In other words, museums are expected to provide visitors with an "experience", ${ }^{67}$ and any museum wanting to reach families must take these changes into account.

Museums are increasingly focused on the public and on creating programs, spaces and exhibitions to encourage visitors to return to the museum. Audience-centred initiatives focus on making museums an appropriate experience for all ages.

Numerous studies confirm that the impacts that affect us in childhood influence our whole lives. ${ }^{8}$ In early childhood, special emphasis should be placed on proper education and guidance, as this will form the basis for a person's socialization and integration later on.

Arts and culture can have a very positive impact on children by helping them develop their body, mind and spirit, as well as encouraging the harmonious development of their personality. This is why fairy tales, rhymes and songs are an integral part of everyday life at home, in kindergartens and schools, as they all help children adjust to the world and overcome their fears.

Among cultural programs, museums can play an important role in raising a child's awareness and intellectual knowledge. In the history of museums, the role of education has become increasingly prominent. Museums have become one of the most important institutions for out-of-school education. That is why it is very important for children to think back over the

\footnotetext{
${ }^{1}$ HALLMAN, Bonnie C. and BEBOW, Mary P. Family leisure, family photography and zoos exploring the emotional geographies of families. In: Social and Cultural Geography 8(6), 2007, p. 871-888.

${ }^{2}$ SCHÄNZEL, Heike A. and SMITH, Karen A. The Socialization of Families Away from Home: Group Dynamics and Family Functioning on Holiday. In: An Interdisciplinary Journal, 36(2), 2014, p 126-143.

${ }^{3}$ POP, Izabela Luiza and BORZA, Anca Factors Influencing Museum Sustainability and Indicators for Museum Sustainability Measurement. In: Sustainability 8, 2016, p. 101-123.

${ }^{4}$ MEHMETOGLU, Mehmet and ENGEN, Marit. Pine and Gilmore's concept of experience economy and its dimensions: an empirical examination in tourism. In: Journal of Quality Assurance in Hospitality \& Tourism, 12(4), 2011, p. 237-255.

${ }^{5}$ HOLBROOK, Morris B. and HIRSCHMAN, Elizabeth C. The experiential aspects of consumption: Consumer fantasies, feelings, and fun. In: Journal of Consumer Research, 9(2), 1982, p. 132-140.

${ }^{6}$ PINE B. Joseph and GILMORE, James H. Welcome to the experience economy. In: Harvard Business Review, 76, 1998, p. 97-105.

${ }^{7}$ BODNÁR, Dorottya, JÁSZBERÉNYI, Melinda, ÁSVÁNYI, Katalin. Az új múzeológia megjelenése a budapesti múzeumokban. [The appearance of new museology in Museums of Budapest]. In: Turizmus Bulletin, 17(1-2), 2017, p. 45-55. [In Hungarian]

${ }^{8}$ See, for example, ANDERSON, D. et al. Children's museum experiences: Identifying powerful mediators of learning. In: Curator: The Museum Journal, 45(3), 2002, p. 213-231.
} 
time they spent at a museum after their visit. However, this experience is influenced by many factors, such as the museum pedagogue, the building in which it is housed, the exhibition and any interactive activities.

Museums are increasingly becoming a place for family experiences. In the present research, therefore, we explicitly explore, from a family perspective, the factors that may be important during family museum visits to encourage families to return.

In this study, we sought to answer the following main research question: RQ: What are the criteria for family-friendly museums?

Our primary sources were in-depth interviews with families, which aimed to identify family-friendly elements in museums, providing a basis from which to formulate a possible definition and criteria for a family-friendly museum.

The concept of "family-friendly" can be interpreted in many different ways. Many authors have already defined it in tourism in relation to hotels ${ }^{9,10,11}$ and festivals ${ }^{12}$, but there is no definition specifically for family-friendly museums. The higher the level at which family-friendly facilities / services are available, the more you can count on a potential competitive advantage for a given museum. It is not enough to provide or maintain family-friendly facilities: additional services must be sought. Depending on their nature, additional services can increase satisfaction and, by putting the element of experience at the forefront, can also be a decisive factor in choosing a particular museum.

The concept of family-friendly museums is not limited to service packages and facilities built around families with small children, but it is certainly an authoritative part of the concept of the term "family-friendly". Basically, two approaches can be identified: the "child-friendly" concept and the "multi-generational" concept, which takes into account the needs of several generations. ${ }^{13}$ The present study focuses on the multi-generational approach for museums.

The structure of the article is as follows: first a literature review is provided with a focus on families as museum visitors; then family motivations and the environmental attributes of museums are discussed. A detailed description of constructive grounded theory is presented. The findings arising from the interviews with museum-visiting families have been developed into a theoretical model which includes the elements or criteria that mark out an ideal family-friendly museum. In the conclusions, the implications of the findings for museum experts are discussed.

\section{Families as museum visitors}

Around the turn of the twentieth century, people became interested in the idea of a children's museum, where the child is equal to the adult and both learn together. These museums encourage children to get to know themselves, respect each other and understand the world

\footnotetext{
${ }^{9}$ CSORDÁS, Tamás, MARKOS-KUJBUS, Éva and ÁSVÁNYI, Katalin. "A gyerekeim imádják, ezért én is imádom” - Családbarát hotelek fogyasztói percepciói online értékelések alapján. ["My children love it, so I also love it” - Consumers perceptions of family-friendly hotels based on online reviews]. In: Turizmus Bulletin, 18(1), 2018, p. 17-28 [in Hungarian].

${ }^{10}$ MINTEL Family Holidays, Leisure Intelligence, London. Mintel International Group, 2004.

${ }^{11}$ CARR, Neil. Children's and Families" holiday experiences. London: Routledge, 2011.

${ }^{12}$ ÁSVÁNYI, Katalin, MITEV, Ariel, JÁSZBERÉNYI, Melinda, MERT, Mentes. Családok fesztiválélménye - két családbarát fesztivál elemzése. [Festival experience of families - analysis of two family-friendly festivals] In: Turizmus Bulletin, 19(3), 2019, p. 30-37. [In Hungarian]

${ }^{13}$ SHUANG, Tiffany and LEE, Ching. Getty Museum Family Room - Educational Issues on Scaffolding and Transfer of Learning. In: International Journal of Art \& Design Education. 2020, publication pending.
} 
around them, as they explore culture, art, science and the environment. In 1899, the Brooklyn Children's Museum opened in New York, launching this movement. Influenced by the example from Brooklyn, several museums were founded between 1913 and 1925, all based on belief in the "learning by doing" method. The 1960s and 70s were an important period in the development of children's museums, focusing on children and their participation, not the exhibition. ${ }^{14}$ Generally speaking, it is usually better for children to visit such museums with family than group visits, as they have better control over what they see and how fast they move around the museum, ${ }^{15}$ which highlights the importance of families as museum visitors.

Indeed, museums are finding that not only children but families themselves represent an essential part and an increasing proportion of museum visitors. ${ }^{16}$ Various studies have shown that more than half of museum visitors are families ${ }^{17}$ Families behave differently to other visitors: they typically spend more time in the museum as a whole and spend more of that time talking ${ }^{18}$ However, each family has different values, knowledge, experiences and expectations ${ }^{19}$ and these factors can be further influenced by cultural differences ${ }^{20}$

Nonetheless, there are few studies on families in a museum context. The greatest attention is paid to family programs, and most research examines the possibility of family learning and interaction.

Nowadays, children represent a great challenge; exposure to technology and different types of entertainment and leisure has made many young people unfocused and easily bored. At the same time, museums need to meet the expectations of parents as well. Family time is becoming more limited, people have many obligations and little free time, and it is not always easy to find programs that provide an enjoyable leisure experience for the whole family.

Examining family visits and community integration of families with autistic children is an important part of family museum research. Publications on this particular issue are very rare. However, there is a clear need to supplement the family-friendly museum criteria with the aspects of this special family group.

\section{Family motivations - Function of museums}

Families' motivations for visiting museums can be diverse, while museums must adapt their functions to fit the needs of families. It is therefore an important issue to reconcile and harmonize these two factors when designing the main functions of museums targeting families.

\footnotetext{
${ }^{14}$ KARADENIZ, Ceren. Children's museums and necessity for children's museums in Turkey. In: Procedia Social and Behavioral Sciences, 2, 2010, p. 600-608.

${ }^{15}$ DIERKING, Lynn D. and FALK, John H. Family behavior and learning in informal science settings: A review of the research. In: Science Education, 78, 1994, p. 57- 72.

${ }^{16}$ DIERKING and FALK, Family behavior..., p. 57- 72.

${ }^{17}$ See, for example, DIAMOND, Judy. The behaviour of family groups in science museums. In: Curator, 29(2), 1986, p. 139-154.

${ }^{18}$ MCMANUS, Paulette M. It's the company you keep: The social determination of learning-related behaviour in a science museum. In: International Journal of Museum Management and Curatorship, 6, 1987, p. 263-270.

${ }^{19}$ BORUN, Minda. Object-based learning and family groups. In PARIS, Scott G. (ed.) Perspectives on object-centered learning in museums. Mahwah, NJ: Erlbaum, 2002, p. 245-260.

${ }^{20}$ BRISEÑO-GARZÓN, Aadriana and ANDERSON, David. "My child is your child": Family learning in a Mexican science museum. In: Curator, 55, 2012, p. 179-201.
} 
Research has shown that learning, socialising and family outings are the main motivating factors for families to visit museums. ${ }^{21}$ Sterry found that families often visit museums for social and entertainment purposes, but that it is also important for them to learn something and spend valuable time together. ${ }^{22}$ Dierking and Falk note that families visit different museums for social or educational purposes. ${ }^{23}$ Several researchers have observed that learning is typically not the primary motivation for families to visit museums ${ }^{24}$ but rather a common outing. ${ }^{25}$

The emphasis on the educational function of museums is increasing by the day. ${ }^{26}$ However, museums serve several other functions for families, in particular as a suitable arena for building personal relationships, discussing family stories and building a common understanding. ${ }^{27}$

Turning our attention to family-friendly museums, the literature shows that the main function of family-friendly museums is to encourage a combination of parent-child interaction, education and shared entertainment. ${ }^{28}$ Family-oriented museums are unique in that they encourage family members to play together, and to enjoy spending time together. ${ }^{29}$

For families, a visit to a museum is mostly a good opportunity to spend quality time together. In fact, families tend to spend more time with each other than focusing on the exhibition itself and the objects on display, suggesting that museums can provide a special environment for family communication. For this reason, an important goal for an effective exhibition is to encourage dialogue between family members. ${ }^{30}$ Museums aimed at families and children have the primary goal of welcoming children and parents and passing on knowledge to them in an interactive way, giving them the opportunity to spend their free time together in an entertaining environment where they learn in addition to having fun. ${ }^{31}$ Sanford examined family learning in 25 different children's museums, and found that time spent in a museum, participation in exhibitions, and interpretive discussions had the greatest impact on learning, suggesting that family-friendly museums provide essential educational functions. ${ }^{32}$

Museums offer two main learning styles for families: guided learning, where family members go around the museum together, and self-directed learning, where individuals can explore sep-

${ }^{21}$ HOOPER-GREENHILL, Eilean and MOUSSOURI, Theano. Researching learning in museums and galleries 19901999: A bibliographic review. Leicester: Research Centre for Museums and Galleries, University of Leicester, 2002.

${ }^{22}$ STERRY, Pat. An insight into the dynamics of family group visitors to cultural tourism destinations: Initiating the research agenda. New Zealand Tourism and Hospitality Research Conference 2004, Victoria University of Wellington, 2004, p. 399-406.

${ }^{23}$ DIERKING and FALK, Family behavior..., p. 57- 72.

${ }^{24}$ KROPF, Marcia Brumit. The Family Museum Experience: A Review of the Literature. In: Journal of Museum Education, 14(2), 1989, p. 5-8.

${ }^{25}$ HILKE, D. D. The family as a learning system: An observational study of families in museums, In: Marriages and Family Review, 13(3), 1989, p. 101-129; BORUN, Minda. Measuring the Immeasurable: A Pilot Study of Museum Effectiveness. Philadelphia: Franklin Institute, 1977.

${ }^{26}$ KARADENIZ, Children's museums..., p. 600-608; HRUBA, Miriama et al. Museum and gallery education and its application in the context of pre-primary education. In: Muzeológia a kultúrne dedicstvo, 7(2), 2019, p. 35-48.

${ }^{27}$ DIERKING and FALK, Family behavior..., p. 57-72.

${ }^{28}$ CONN, Steven. Do museums still need objects? Philadelphia: University of Pennsylvania Press, 2010; FALK, John H. and DIERKING, Lynn D. Learning from museums: Visitor experiences and the making of meaning. Lanham: AltaMira Press, 2000 .

${ }^{29}$ GARNER, Betsie. Mundane Mommies and Doting Daddies: Gendered Parenting and Family Museum Visits. In: Qualitative Sociology, 38, 2015, p. 327-348.

${ }^{30}$ SILVERMAN, Lois H. Johnny Showed Us the Butterflies. In: Marriage \& Family Review, 13(3-4), 1989, p. 131-150

${ }^{31}$ KARADENIZ, Children's museums..., p. 600-608.

${ }^{32}$ SANFORD, Camellia W. Evaluating family interactions to inform exhibit design: Comparing three different learning behaviors in a museum setting. In: Visitor Studies, 13(1), 2010, p. 67-89. 
arately and meet occasionally. In the second case, the role of parents becomes more important in family learning. Factors influencing family learning include: prior knowledge and experience, individual and group schedules, gender and the age of parents and children. ${ }^{33}$

Research on interactions within the family ${ }^{34}$ suggests that parent-child interactions are more effective in exhibitions where parent involvement is strengthened and encouraged, if only because of the need for the parents to go beyond verbal interaction and engage in a physical, hands-on way. ${ }^{35}$

The aim of family-friendly exhibitions is to get as many families as possible to visit museums (attracting power), to encourage them to stay there as long as possible (holding power) and to facilitate better comprehension of the message of the displays (communication power). ${ }^{36}$

Museums are informal learning institutions that provide opportunities for social inclusion for people with disabilities. ${ }^{37}$ Langa et al. found that the most important motivations for families with disabled children to visit museums were: to be treated as members of a group, to be mentally stimulated, to gain more information, and to experience new things. Two other important aspects for such families were spending quality family time together and the child's/ children's interest in the exhibition. Interacting with other museum visitors, relaxation and socialization were not found to be important motivations. ${ }^{38}$

\section{Environmental features of museums - Family experience}

According to Kropf, when visiting exhibitions, the experience of the family is most influenced by the type of exhibition, the environment of the museum and the interests of family members. ${ }^{39}$ Since the aim of our research is to determine the elements that make a museum family friendly, regardless of the museum's profile or the scope of the family's interests, the first and third of these factors are not considered in the present study. Melton developed a family activity model (FAM) in which he interprets family experiences in terms of the activity environment (environment novelty) and family interaction (interaction between family members). ${ }^{40}$ During the visit, the family-friendliness of the museum is determined by the environment that the museum creates, which influences the experiences of the families. The museum environment can be divided into the following sub-areas:

- factors independent of the exhibition, such as prior information, physical environment, people in the museum, activities outside the exhibition;

- factors related to the exhibition: displayed objects, programs, rooms for children;

- a combination of all of these.

\footnotetext{
${ }^{33}$ DIERKING and FALK, Family behavior..., p. 57-72.

${ }^{34}$ SWARTZ Mallary I. and CROWLEY Kevin Parent Beliefs about Teaching and Learning in a Children's Museum. In: Visitor Studies, 7(2), 2004, p. 4-16; SHINE, Stephanie and ACOSTA, Teresa Y. Parent-child social play in a children's museum. In: Family Relations, 49, 2000, p. 45-52.

${ }^{35}$ BROWN, Christine. Making the most of family visits: Some observations of parents with children in a museum science centre. In: Museum Management and Curatorship, 14(1), 1995, p. 65-71.

${ }^{36}$ BORUN, Minda and DRISTAS, Jennifer. Developing family friendly exhibits. In: Curator: The Museum Journal, 40, 1997 p. $178-196$.

${ }^{37}$ LUSSENHOP, Alexander et al. Social Participation... p. 122-137.

${ }^{38}$ LANGA, Lesley A. et al. Improving the museum experiences... p. 323-335.

${ }^{39}$ KROPF, Marcia Brumit. The Family Museum... p. 5-8.

${ }^{40}$ MELTON, Karen K. Family Activity Model: Crossroads of Activity Environment and Family Interactions. In: Family Leisure, Leisure Sciences, 39(5), 2017, p. 457-473.
} 
The online presence of the museum is a factor that provides prior information for families before getting to the museum itself. However, the literature contains little to address the importance of this type of communication. Preliminary information, ticket prices and opening hours are all factors that can help or hinder families' decision to visit. Research by the Dutch Museum Association highlights the provision of free admission to some institutions as a family-friendly factor. $^{41}$

When entering the museum, the physical environmental factor that affects families is the extent to which it feels family-friendly and appropriate for children. ${ }^{42}$ The clarity of the main information signs is an important criterion, as well as child-friendly displays at a height that can be viewed by young children and possibly even those in strollers. ${ }^{43}$

Activities outside the exhibitions can also be very attractive to families, such as a playground and dining facilities. ${ }^{44}$ With regards to the latter, restaurants should offer affordable, appealing, high quality food for children. ${ }^{45}$

The role of museum staff is very important: friendly and helpful staff have been highlighted in several studies. ${ }^{46}$ While examining the quality of service in a children's museum, it was found that the empathy of staff was the most important factor. ${ }^{47} \mathrm{~A}$ large number of visitors consider their interaction with the staff to be the most memorable feature of their visit to the museum. Museum employees help visitors in active learning, encouraging them to communicate and interact. It is important to constantly train staff to be prepared for any situation, as they have to work with several generations at the same time. ${ }^{48}$

Other museum visitors also greatly influence the experience of families. For example, if people are standing in front of the exhibits, blocking the children's view, families will tend to move on, only stopping where they have access. ${ }^{49}$

Among the factors related to the exhibition itself, there are many possibilities in terms of the displayed objects to strengthen the family-friendly nature of the museum. It is important that the exhibited objects are well lit so that children can see them clearly, and, where permitted, touch them safely. ${ }^{50}$ Children learn most by asking questions, playing and commenting on games, discovering things (smelling, touching, tasting, etc.), so there is a need for images and symbols that children can read or listen to in their own language, and that they can physically interact with. ${ }^{51}$ The experience is facilitated by tangible displayed objects and devices that affect

\footnotetext{
${ }^{41}$ BOER B. Children Visiting Museums. Investing in the audience of the future. Den Haag: Netherlands Museums Association, 2011.

${ }^{42}$ PISCITELLI, Barbara and ANDERSON, David Young children's Perspectives of Museum Settings and Experiences. In: Museum Management and Curatorship, 19(3), 2001, p. 269-282.

${ }^{43}$ STERRY, An insight into..., p. 399-406.

${ }^{44}$ KROPF, The Family Museum..., p. 5-8.

${ }^{45}$ STERRY, An insight into..., p. 399-406.

${ }^{46}$ STERRY, An insight into..., p. 399-406.

${ }^{47}$ MAHER, Jill K. et al. Measuring Museum... p. 29-42.

${ }^{48}$ VILLA, Lindy Rediscovering Discovery Rooms: Creating and improving family-friendly interactive exbibition spaces in traditional museums. Dissertation for Master of Arts. School of Education and Liberal Arts. John F. Kennedy University, 2006, p.142.

${ }^{49}$ KROPF, The Family Museum..., p. 5-8.

${ }^{50}$ KROPF, The Family Museum..., p. 5-8.

${ }^{51}$ DOOLEY, Caitlin McMunn and WELCH, Meghan M. Nature of Interactions Among Young Children and Adult Caregivers in a Children's Museum. In: Early Childhood Education Journal, 42, 2014, p. 125-132.
} 
all the senses, ${ }^{52}$ and these have been shown to increase the time spent at the exhibition. ${ }^{53}$ At the same time, if children have their own experiences related to the theme of the exhibition, they will have a more positive experience than in the case of practice-oriented, inclusive and multi-sensory exhibitions ${ }^{54}$ which shows that the family-friendly design of the physical environment itself is not sufficient to attract family visitors.

The experience of visiting a museum can be greatly enhanced by programs associated with the exhibition. The organization of events related to holidays and celebrations is typical in museums, as well as programs to help discover the exhibition or the collection (such as children's guides or treasure hunts). In several institutions, special programs are offered to children who come with their families. ${ }^{55}$ In children's museums, programs and exhibitions are designed to encourage children to use their creativity during their visit. These kinds of interactive programs allow children to tackle real life problems and gain practical experience and knowledge. ${ }^{56}$ For example, Sterry found that family visitors to the Victoria and Albert (V\&A) Museum in the UK mostly came to see the general collection, but many stated they were also happy to visit special exhibitions, workshops or family-oriented programs and expected their children would be deeply interested by the museum. ${ }^{57}$ There are museum initiatives that expect active participation as part of the exhibition, for example through dressing and acting opportunities ${ }^{58}$.

A room specially designed for children can promote practical learning, encourage curiosity and creativity, and provide an opportunity to explore, but the size of the room can also be a decisive factor. ${ }^{59}$ Kids Island in Australia is a children's museum aimed at $0-5$ year-olds that has developed a game-based learning environment to facilitate shared discovery and interaction between children, parents, peers and museum staff. ${ }^{60}$ In several cases museums use so-called exploratory, liberating rooms to invite people to participate in an interactive, creative and active exhibition. These interactive spaces provide a greater opportunity for learning than traditional exhibitions, as they do not only require passive observation, but also introduce various tasks, lights and sound effects to provide visitors with an exploratory experience. In addition, these opportunities help families communicate more and learn from each other through tasks. ${ }^{61}$

If parents and children interact together, joint attention is significantly more likely to develop, which has proven to be an effective tool to support family learning. ${ }^{62}$ However, in most cases, parents are only willing to participate in games and explorations in the museum if the context is appropriate and favourable for adults. ${ }^{63}$

\footnotetext{
52 PISCITELLI and ANDERSON, Young children's..., p. 269-282.

53 KROPF, The Family Museum..., p. 5-8.

${ }^{54}$ PISCITELLI and ANDERSON, Young children's..., p. 269-282.

${ }^{55}$ BOER, Children Visiting...

${ }^{56}$ KARADENIZ, Children's museums..., p. 600-608.

${ }^{57}$ STERRY, An insight into..., p. 399-406.

${ }^{58}$ JOHANSON, Katya and GLOW, Hilary "It's not enough for the work of art to be great": Children and Young People as Museum Visitors. In: Journal of Audience and Reception Studies, 9(1), 2012, p. 26-42.

${ }^{59}$ KELLY, Lynda. Play, wonder and learning: Museums and the preschool audience. Australian Research in Early Childhood Education 10th Annual Conference, Canberra, Australia, 2002.

${ }^{60}$ DOCKETT, Sue, MAIN, Sarah and KELLY, Lynda. Consulting Young Children: Experiences from a Museum. In: Visitor Studies, 14(1), 2011, p. 13-33.

${ }^{61}$ VILLA, Rediscovering Discovery... p. 142.

62 POVIS, Kaleen Tison and CROWLEY, Kevin Family learning in object-based museums: The role of joint attention. In: Visitor Studies, 18(2), 2015, p. 168-182.

${ }^{63}$ KANHADILOK, Peeranut and WATTS, Mike Adult play-learning: Observing informal family education at a science museum, In: Studies in the Education of Adults, 46(1), 2014, p. 23-41.
} 
In terms of the museum environment, the visiting experience of families with disabled children is enhanced by the following factors ${ }^{64}$

In terms of factors independent of the exhibition, it is worth highlighting the importance of the website, from which visitors can obtain preliminary information about the museum environment and the expectations of behaviour in the museum; in some cases, there may even be a separate website / menu item for families of children with disabilities. Websites can also provide information on which periods are crowded, highlighting quiet periods appropriate for autistic people; they may also draw attention to quiet spaces, which is another important criterion for many on the autism spectrum. When entering the museum and moving around it, it is also important to have spacious exhibition spaces or a quiet room where people can relax. It is also very important to provide clear signs, plenty of detailed maps, indications of the nearest exits and toilets, which can provide a safe environment. The opportunity to interact with the museum staff and volunteers is a major factor in the quality of museum experience in this case, as it is important that family members can ask for help and support if needed. It is very important for the museum to organize special events for parents with disabled children where there are fewer crowds, less stress, and the children can easily connect with others.

Regarding factors related to the exhibition, the experience for many children with disabilities can be enhanced through multisensory interactive exhibitions.

According to Lussenhop et al., the components of a successful visit for families with disabled children are: fun, involvement, learning, sufficient time, a pleasant and relaxed experience, something to connect with, and the intention to return. On the other hand, barriers include the cost of a visit, loud noises, crowds, and the reactions of other visitors during an average museum visit, all of which can prove frustrating for such families. ${ }^{65}$

\section{Research methodology}

The aim of this study was to get to know and understand museums better, and to explore the layers of meaning of the family-friendly museum system supported by empirical research. Based on the literature, family-friendly museums raise a number of issues that could be researched qualitatively to understand and explore them better. The main questions of our research are: Why do families go to a museum? What factors influence families' museum experience? What would an ideal family-friendly museum look like?

\section{Research objectives and research questions}

In our research, we wanted to explore the process of visiting a museum and the factors that determine the museum experience and characterise the ideal museum from the perspective of families, through the analysis of in-depth interviews conducted with visiting families. The aims of our research were:

- $\quad$ to determine the criteria the families considered when selecting the museum or exhibition they want to visit;

- $\quad$ to explore the factors influencing the museum experience; and

- to analyse experience factors.

\footnotetext{
${ }^{64}$ LANGA et al. Improving the museum experiences..., p. 323-335; LUSSENHOP et al. Social Participation..., p. 122-137; KULIK and FLETCHER, Considering the Museum..., p. 27-38.

${ }^{65}$ LUSSENHOP et al. Social Participation..., p. 122-137.
} 
In formulating our research questions, we relied on the literature and the experience of museum professionals. To examine the concept of a family-friendly museum from the family members' perspectives, we focused on Hungarian families where a museum visit is a common family experience and the child is accompanied by both parents.

After formulating our research problem, the following main research question and sub-questions were formulated:

RQ: What are the criteria for family-friendly museums?

Q_1. What are the most important motivating factors for families to visit a museum?

Q_2. What are the factors that affect families 'museum experience?

Q_3. What are the characteristics of an ideal family-friendly museum?

\section{Research methods}

In our research, we conducted semi-structured in-depth interviews. We interviewed a total of 10 families. During the interviews, we followed the pre-defined questions, but not in a fixed order; rather, we adapted the course of the interviews to the given situation.

The grounded theory (GT) method $^{66}$ was chosen for the research. In addition to the two main methodological approaches, Glaser's ${ }^{67}$ classical and Strauss-Corbin's, ${ }^{68}$ many other subtypes have appeared in the literature. For our study, we chose the constructivist approach, which is related to Charmaz's methodology, ${ }^{69}$ the main distinguishing feature of which is that it recognizes that the researcher him/herself is an important part of the research process. This method allows for a preliminary mapping of the literature and for it to influence the researcher's thinking and provides an opportunity to use preliminary theoretical frameworks. As theoretical and practical experts on the museum theme, we have gained significant previous experience that influenced our attitude and decision in our choice of method.

\section{Research group}

The research was carried out in Hungary. Non-probability sampling was used and families included in the sample were selected based on a defined set of criteria. One of our expectations was that the sample should include families who visit the museum regularly and have done so at least once in the past year. Two additional conditions were that both parents must be present during the family museum visit and that the children were younger than 14 years old. Most of the families interviewed live in Budapest and in the catchment area of the capital. A total of 20 in-depth interviews (10 mothers and 10 fathers) were used. The average length of the interviews was 30-45 minutes, and the digitally recorded audio files were later transcribed. When analysing the sample, the anonymity of the parents was ensured and the following names were used to cite the answers: mothers: \#M1 - \#M10, fathers: \#F1 - \#F10. The museum experiences of the parents participating in the study were related to different museums (art, science, local history), in order to obtain a broad picture of families' expectations, as our goal was to be able to define family-friendly criteria regardless of the museum's profile.

\footnotetext{
${ }^{66}$ MITEV, Ariel. Grounded theory, a kvalitatív kutatás klasszikus mérföldköve. [Grounded theory, a classic milestone in qualitative research]. In: Vezetéstudomány, 43(1), 2012, p. 17-30. [In Hungarian]

${ }^{67}$ GLASER, Barney G. Basics of Grounded Theory Analysis. Mill Valley: The Sociology Press. 1992.

${ }^{68}$ STRAUSS, Anselm and CORBIN, Juliet. Basics of Qualitative Research: Grounded Theory Procedures and Techniques. Newbury Park: Sage. 1990.

${ }^{69}$ CHARMAZ, Kathy. Grounded theory: objectivist and constructivist method. In: DENZIN, Norman K. and LINCOLN, Yvonna S. (eds) Handbook of Qualitative Research. California: Sage, 2000, p. 509-536.
} 


\section{Data analysis}

The data obtained from the analysis of the interviews were processed in open coding. We typed the interview texts word-for-word, then numbered each line and went through line by line underlining the codes we considered important line by line. In the next step, the codes were organized into categories and the resulting groups were given content names. We organized our categories into thematic units that reflected the family as museum visitors, family motivations, factors influencing the museum visit experience, and the process and criteria system of family-friendly museum visits. After exploratory open coding, the connection points between the given categories were identified (axial coding). Based on the representation method developed by Corley and Gioia, ${ }^{70}$ we show how we grouped the raw data into concepts and then topics and what dimensions we developed by integrating all aspects of the theory (Figure 1).

Fig. 1: The structure of codes

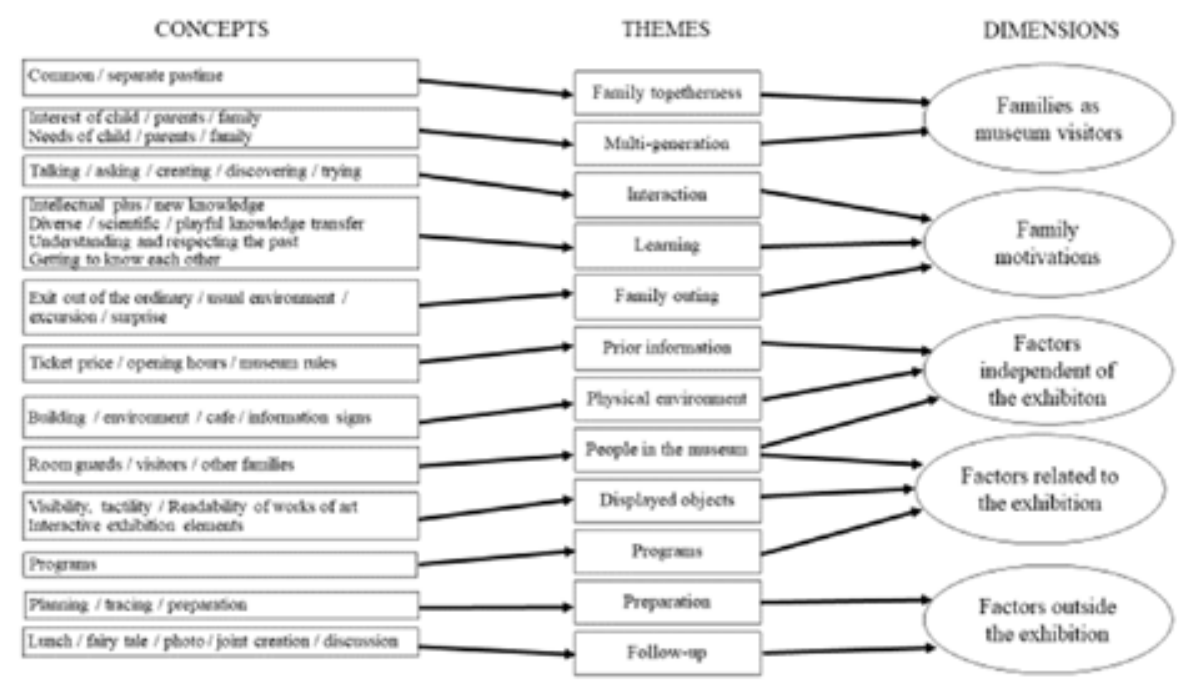

Source: prepared by author based on graphical structure schema of Corley and Gioia ${ }^{71}$

\section{Results and interpretation}

Almost every family visits a museum with a different background of knowledge and experience. Their experiences related to the given topic are variable. They come with children of different ages. The question of whether the visit to a museum is a part of a larger trip or is arranged instead of a missed weekend program is also an influencing factor. In the same museum, conditions may change from time to time: some exhibitions may attract a large number of visitors, huge crowds may form and, as a result, additional protective measures may be introduced to protect vulnerable artefacts, making it difficult for families to comfortably visit the museum. The mood, interest and physical condition of parents and children also greatly influence how they later remember a visit to a museum. The aim of our research is to explore the most important elements of a family-friendly museum that can be applied independently of these hidden dimensions. In the next section, we summarize the results based on the dimen-

\footnotetext{
${ }^{70}$ CORLEY, Kevin G. and GIOIA, Denis A. Identity ambiguity and change in the wake of a corporate spin-off. In: Administrative Science Quarterly, 49(2), 2004, p. 173-208.

${ }^{71}$ CORLEY and GIOIA, (2004) Identity ambiguity... pp. 173-208.
} 
K. Ásványi - Zs. Fehér - M. Jászberényi: The Family-Friendly Museum: Museums through the eyes of families

sions that are relevant to creating a family-friendly character.

\section{Families as museum visitors}

In almost all interviews, the parents said they prefer family museum visits to other leisure programs because it improves family togetherness, which was a recurring element in almost all interviews, as expressed by \#M1: "We rarely get together like this in everyday life."

However, it is important that this time spent together is a positive experience and relaxing for everyone, that the children do not have to be constantly disciplined, and that they are involved in the exhibition so that the parent can immerse themselves in the topic. For example, "It is difficult to go to a museum with a family: the child is hungry, she or he has to go to the bathroom or just gets bored" (\#F1).

It is an important factor to have shared experiences: "they can be together and enjoy the exhibition and the games all the way" (\#M2). Family members should have fun not just separately, but also enjoy the museum visit together: "good to do and to experience something together" (\#M3).

We examined the museum visit experience from the perspectives of family members of different generations, and explored how parents define when the family, parent or child also feels good in the museum: \#F2 suggested a good experience was had by all "If the museum provides a program that the child is happy to deal with, and the parent/grandparent as well." For many families, the attitude is that the child comes first, and if he or she feels good, the parent will also feel good, although that does not necessarily mean a shared experience. However, there are programs in which all ages can find the right entertainment for them, "for example, a child imitates animals, mother reads educational texts, and father photographs them" (\#F3).

\section{Family motivations}

One motivation for a museum visit is that it offers families the opportunity to move together through the experience: "We manage to break away from everyday life, we are completely committed, we have finally found a program that is both useful and an experience" (\#M4). A visit to a museum can be a surprise for a child, or part of a trip, the point is the common outing and enter "another dimension" (\#M4).

There are parents who mention learning as the main factor of motivation: "I almost always feel good, I always find something interesting, and I feel best when I learn something new that complements my previous knowledge" (\#F4). Meanwhile, for other parents, a visit to a museum is enjoyable if it allows them to interact with their children, talk and explore the exhibits in a diverse, playful way: "I like the bustling, playful places where it gives something plus, not just dry material" (\#F5).

Within the family, the motivations of the mother and father may also differ and they may formulate criteria for an enjoyable museum program for the child based on different perspectives. For example, in one family, from the mother's point of view, "understanding and respecting the past" and expanding knowledge were the most important things for her child: she considered the experience a positive one "if someone tries to pass on knowledge from their point of view, explain things at their [the child's] level, lead them and they can marvel at things, participate in them, touch them and create" (\#M5). From the father's perspective, the important thing is to broaden the child's horizons and make the most of the social learning that arises from the visit: "we learn a lot about each other, we talk a lot afterwards, we try to set a good example for the child" (\#F5). 


\section{Environmental features of museums - Family experience}

During the in-depth interviews, we asked parents to recall their most positive and negative museum experiences. In analysing the recalled memories, we identified several experience factors that are closely related to each other and significantly influence the experience of museum visits, and their combined presence can have a long-term impact on the family's museum visiting habits.

\section{Factors independent of the exhibition}

The characteristics of a family-friendly museum that emerged from the in-depth interviews confirmed the results noted in the existing literature, but provided a much more detailed picture of how families experience museum visits, how they prepare for them, what different aspects come to the fore depending on the child's age and what individual expectations of exhibitions and museum services parents have.

For families, visiting a museum can be very costly, depending on how many family members take part, so one thing that matters a lot is the ticket price, to what age discounts apply and to what extent. As \#F6 notes, "It's good to have child(-rate) ticket or when it is free for them" (\#F6), highlighting that this is an important factor in designing family-friendly access. However, parents also mentioned that in many cases, "expensive souvenir items" evoked the negative feeling of being unable to buy a memory for their child in connection with their museum experience.

For family visits, smaller exhibitions and notification of periods when large crowds can be avoided are ideal; "short opening hours" can also be a problem for families.

In terms of the physical environment of the museum, old buildings can either be an obstacle to barrier-free design, or it can make services more difficult. The "lack of information signs" was often mentioned as a problem, with families getting lost, returning to the same site several times, and/or becoming separated and struggling to find each other.

An important aspect highlighted by parents was the importance of cultured and courteous behaviour by museum staff and their treatment of children. For example, \#F7 the experience positive "If they [staff] communicate with them [children] according to their level. The educators need to be prepared and open to children's associations, so very good dialogues can be developed". It can be a negative experience if "the behaviour of the guard is not visitor-friendly" or if the visitors feel "the guards were constantly in our corner". It can also be difficult when there is a large crowd or if parents have to stand in line with a child too much, and of course visitors might also be disturbed by each other.

\section{Factors related to the exhibition}

According to our informants, children enjoy visiting a museum if they can gain insight into things, if they can evolve, and if they do not have to behave like an adult; a child might have a negative experience if "he notices that somebody is watching what he is doing, how much time he spends in front of a picture" (\# F8).

An important aspect in art museums is the opportunity for children to create in addition to contemplate, whereas in a history museum it is important for children to be able to experience what they see embedded in an interesting story. Museum experts can greatly influence the positive experience of families if they approach the design appropriately, from the perspectives of children and adults. This was well understood by respondents, who noted that it was important for museum educators to "know that the needs of adults and children are different, since artworks are also 
approached differently by them, and they can separate and connect children and adults at the right time" (\#F9).

Guided tours through the exhibition for all members of the family should be conducted in an interpretable and enjoyable way. One satisfied father noted, "The program was led by very professional museum educators who took us through an exhibition which was not easy to interpret. The child really enjoyed being occupied and we were also happy that the child was enjoying it" (\#F10).

An important feature of family-friendly exhibitions is to provide hands-on experience. This can be difficult to achieve in many museums, because it also depends a lot on the theme of the exhibition. "It is good to present the exhibition in an interactive, playful way, there are tangible objects, it affects all our senses and we can learn from it" (\#F6). In terms of displayed objects, families focus on visibility, tactility, readability, all presented in an interactive way.

In connection with the exhibition, it is important that, in addition to the objects on display, there are programs that specifically target families. This is because, at first hearing, people might not necessarily think that a museum can be family-friendly; however, the appropriate program can motivate families to come to a museum: "We've been to the museum without kids before, but not with the family yet. We've seen a family weekend program. We didn't really know much about it, we thought we'd go together because both my wife and I love modern art. We were curious what we could do here with a child, we didn't have many expectations" (\#F5).

\section{Factors outside the exhibition}

Parents, as experienced museum guests, also articulated how much responsibility the parent has in preparing for the museum visit and selecting an exhibition that suits the child's interests. In addition to taking into account the time needed for the museum visit, the child's mental health, physical condition and endurance must also be considered. It is also important that the parent feels comfortable in the museum and discusses the experiences gained in the museum even after the museum visit.

Our research outlined the need to examine families' museum experiences in a much broader context. The experiences gained in a given museum are preceded by a preparation phase, and the visit is followed by a follow-up phase.

The preparation phase is when the family starts to plan a visit to the museum and looks up preliminary information. As one father explains: "We like to go to a museum, [but] before that the children have to prepare for the museum visit. We discuss what they will see, and when we get there they already have some information" (\#F3).

The follow-up phase begins when after leaving the exhibition site, but while the family is still in the museum area, which makes it possible to extend the museum experience, for example, by having coffee or lunch in the museum garden or trying out the museum playground. As one parent puts it, "Afterwards we let off steam" (\#M6). A joint photo also prolongs the museum experience, producing which the family can talk about afterwards. Another option is to create something together at home: "... because we talked about it at home afterwards, and the child made drawings in Korniss's style. It was a memorable and good experience because it had an 'afterlife"” (\#M7).

\section{Discussion and conclusion}

In our study, our goal was to explore the criteria that make a museum family-friendly through in-depth interviews based on grounded theory. Based on the literature and research results, this study proposes a framework for family-friendly museums as shown in Figure 2. 
Based on our findings, it can be concluded that the family represents a special type of visitor for museums. This is mostly determined by the fact that museums need to be able to provide an experience for several age groups at the same time, so a multi-generational approach is needed. Families' motivations can essentially be categorised into three main groups: interaction, learning, and a family outing. The primary motivation may vary from family to family, but it is important for museums to provide all these functions. Museums should encourage interaction, which can take place within the family, between families, or between the family and museum experts and educators. ${ }^{72}$ In relation to learning, museums are responsible for sharing knowledge. In terms of a joint family outing, it is also the task of the museum to create a suitable program for several generations to experience at the same time, which can be quite a challenge.

\section{Fig. 2: Theoretical model}

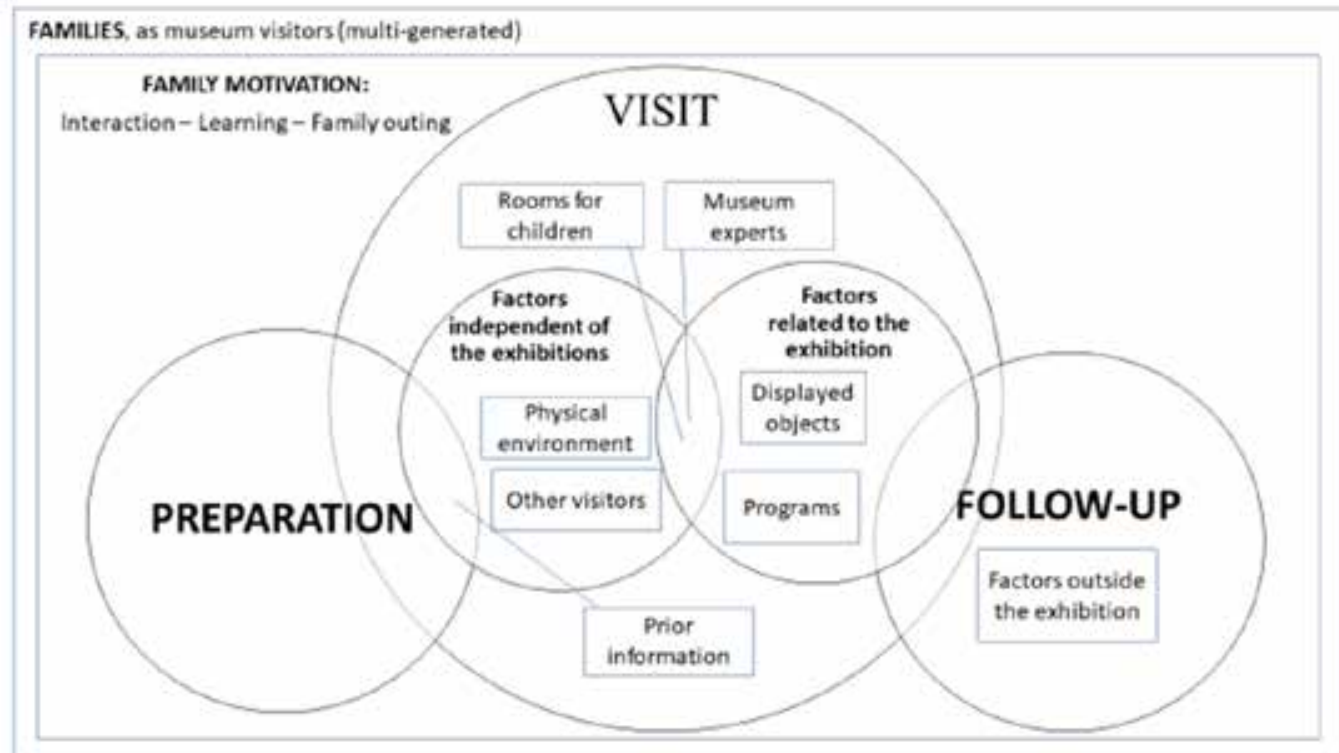

Source: prepared by authors

Several articles have contributed to the literature by exploring families as museum visitors. Some relevant studies have specifically investigated in the motivations of families to visit museums. However, these previous studies have focused on only one aspect of the family-friendly elements of museums. The present study adds to previous literature by offering a model of the family-friendly museum and exploring the criteria necessary for the realization of a family-friendly museum.

The results from the present study have the potential to be used by museums that target families. From the interviews with parents, we established some criteria for family-friendly museums which we summarise below. We identified aspects that museums may need to pay more attention during the preparation, visit and follow-up phases, and pin-pointed the factors that are necessary to create an ideal family-friendly museum.

The preparation phase. In-depth interviews revealed that the majority of families prepare to visit the museum, gather information in advance, and judge the museum, exhibition and period

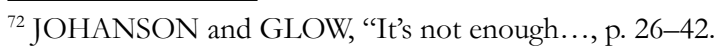


of visit carefully. Museum experts can plan and communicate their services more effectively by understanding the perspectives of families. Families may struggle to enjoy a visit in a crowded exhibition space, so it is advisable to highlight the ideal period for family visits on the museum's website or, ideally, mark time zones when only families are expected to visit, and when museum educational sessions are provided for all family members.

Another important factor is to evaluate the content/thematic aspects of exhibitions based on the perspectives of families. Not all exhibitions are interesting for all ages and there are some that do not engage younger children at all; visiting an age-inappropriate exhibition might evoke negative memories and even influence the family's desire to visit museums again in the long run. To help parents plan their visit, museums can also place downloadable information and educational materials on their website, which, in addition to practical preparation, allows parents to discuss the topic of the exhibition at home, thus helping to deepen the child's involvement when they finally visit.

It is also very important to provide discounts for families. Unfortunately, if visiting a museum comes at a high cost for families, it is a major drawback. Children are the museum visitors of the future - or at least, they may become so if they have positive experiences with their family while young. It is worth museums taking these aspects into account when setting their ticketing policies and to consider offering families discounted tickets or annual passes.

The visit phase. To ensure a positive museum experience, it is recommended that museums prepare staff to deal with families. Visitors with families can be spared a lot of negative experiences if the reception staff and the guards in the exhibition space adopt a family-friendly approach and attitude. There is a great need on the part of families to provide a separate room for children.

Signage and information is another important aspect. Rather than prohibitory signs, the signage should help people orient themselves in the museum space and provide information and education insights about exhibitions. Setting up information points can also help in this regard. Families benefit from support to discover the museum and the exhibitions through films and guided walks led by museum educators.

To support families, museums should make exhibits accessible and create interactive exhibition elements, for which the involvement of digital devices provides many new opportunities. Families will feel comfortable in the museum if the museum is a source of new experiences for all members, especially those can be implemented through discovery and interaction.

The follow-up phase. The museum visit does not end on leaving the exhibition itself. Indeed, it is important to offer families additional program options that complete the visit. There are pleasant walkways and playgrounds in the gardens of many museums, all of which are worth drawing the attention of families to as they leave the exhibition. According to the reports from parents, a joint conversation about what they have seen, or further activities undertaken at home, such as drawing and viewing photographs, are also part of the museum experience. A useful guide for this might be a brochure or a workbook that can be downloaded from the website.

Finally, museums should ask families to give feedback on their visit, from which they can gain greater understanding of this perspective and improve their services. It can also be experienced as a positive gesture to thank parents for bringing their children to the museum.

Despite the richness of the contributions from our informants, our study has limitations. The first is that only Hungarian families were included in the sample. Thus the study could be 
enhanced in the future by interviewing families from other countries, which may reveal other perspectives. Other research into family tourism also analyses drawings made with children, which can provide additional information to support the development of family-friendly museum criteria. Other studies have examined families with disabilities as museum visitors; seeking the perspectives of such families would help achieve a more complete picture of family-friendly factors.

The family-friendly criteria identified on the basis of the interviews are in themselves worth further research, thus we consider it important to supplement our qualitative results with primary research that also measures quantitative elements. In the present study, we conducted interviews with families only, and developed our model based on the examination of the demand side. It would be worth also undertaking research on the supply side, that is, conducting interviews with museum specialists, to supplement our results and compare perspectives from the supply and demand side. An even more detailed definition of the criteria could be facilitated by undertaking benchmarking exercises in which we examine the website of family-friendly museums internationally using a content analysis method.

\section{References}

ANDERSON, D., B. PISCITELLI, K. WEIER, M. EVERET'T, and C. TAYLER. (2002). Children's museum experiences: Identifying powerful mediators of learning. In: Curator: The Museum Journal, 45(3), p. 213-231.

ÁSVÁNYI, Katalin, MITEV, Ariel, JÁSZBERÉNYI, Melinda, MERT, Mentes. (2019). Családok fesztiválélménye - két családbarát fesztivál elemzése. [Festival experience of families analysis of two family-fridenly festivals]. In: Turizmus Bulletin 19(3), p. 30-37. [In Hungarian]

BODNÁR, Dorottya, JÁSZBERÉNYI, Melinda, ÁSVÁNYI, Katalin. (2017). Az új múzeológia megjelenése a budapesti múzeumokban. [The appearance of new museology in Museums of Budapest]. In: Turizmus Bulletin, 17(1-2), p. 45-55. [In Hungarian]

BOER B. (2011). Children Visiting Museums. Investing in the audience of the future. Den Haag: Netherlands Museums Association.

BORUN, Minda. (1977). Measuring the Immeasurable: A Pilot Study of Museum Effectiveness. Philadelphia: Franklin Institute.

BORUN, Minda. (2002). Object-based learning and family groups. In PARIS, Scott G. (ed.) Perspectives on object-centered learning in museums. Mahwah, NJ: Erlbaum, p. 245-260).

BORUN, Minda and DRISTAS, Jennifer. (1997). Developing family friendly exhibits. In: Curator: The Museum Journal, 40, p. 178-196.

BRISEÑO-GARZÓN, Aadriana and ANDERSON, David. (2012). "My child is your child": Family learning in a Mexican science museum. In: Curator, 55, p. 179-201.

BROWN, Christine. (1995). Making the most of family visits: Some observations of parents with children in a museum science centre. In: Museum Management and Curatorship 14(1) p. 65-71.

CARR, Neil. (2011). Children's and Families' holiday experiences. London: Routledge.

CHARMAZ, Kathy. (2000). Grounded theory: objectivist and constructivist method. In: DENZIN, Norman K. and LINCOLN, Yvonna S. (eds) Handbook of Qualitative Research. California: Sage, p. 509-536. 
K. Ásványi - Zs. Fehér - M. Jászberényi: The Family-Friendly Museum: Museums through the eyes of families

CONN, Steven. (2010). Do museums still need objects? Philadelphia: University of Pennsylvania Press.

CORLEY, Kevin G and GIOIA, Denis A. (2004). Identity ambiguity and change in the wake of a corporate spin-off. In: Administrative Science Quarterly, 49(2), p. 173-208.

CSORDÁS, Tamás, MARKOS-KUJBUS, Éva and ÁSVÁNYI, Katalin. (2018). "A gyerekeim imádják, ezért én is imádom" - Családbarát hotelek fogyasztói percepciói online értékelések alapján. ["My children love it, so I also love it" - Consumers perceptions of family-friendly hotels based on online reviews]. In: Turizmus Bulletin 18(1) p. 17-28. [In Hungarian]

DIAMOND, Judy. (1986). The behaviour of family groups in science museums. In: Curator, 29(2), p. 139-154.

DIERKING, Lynn D. and FALK, John H. (1994). Family behavior and learning in informal science settings: A review of the research. In: Science Education, 78, p. 57-72.

DOCKET'T, Sue, MAIN, Sarah and KELLY, Lynda. (2011). Consulting Young Children: Experiences from a Museum. In: Visitor Studies, 14(1), p. 13-33.

DOOLEY, Caitlin McMunn and WELCH, Meghan M. (2014). Nature of Interactions Among Young Children and Adult Caregivers in a Children's Museum. In: Early Childhood Education Journal, 42, p. 125-132.

FALK, John H. and DIERKING, Lynn D. (2000). Learning from museums: Visitor experiences and the making of meaning. Lanham: AltaMira Press.

GARNER, Betsie. (2015). Mundane Mommies and Doting Daddies: Gendered Parenting and Family Museum Visits. In: Qualitative Sociology, 38, p. 327-348.

GLASER, Barney G. (1992). Basics of Grounded Theory Analysis. Mill Valley: The Sociology Press.

HALLMAN, Bonnie C. and BEBOW, Mary P. (2007). Family leisure, family photography and zoos exploring the emotional geographies of families. In: Social and Cultural Geography, 8(6), p. $871-888$.

HILKE, D.D. (1989). The family as a learning system: An observational study of families in museums. In: Marriages and Family Review, 13(3), p. 101-129

HOLBROOK, Morris B. and HIRSCHMAN, Elizabeth C. (1982). The experiential aspects of consumption: Consumer fantasies, feelings, and fun. In: Journal of Consumer Research, 9(2), p. 132-140.

HOOPER-GREENHILL, Eilean and MOUSSOURI, Theano (2002). Researching learning in museums and galleries 1990-1999: A bibliographic review. Leicester: Research Centre for Museums and Galleries, University of Leicester.

HRUBA, Miriama, KACIREK, Lubosi, NEMCOVA, Jana, OSAD'AN Róbert and SZENTESIOVA, Lenka. (2019). Museum and gallery education and its aplication in the context of pre-primary education. In: Muzeológia a kulturne dedicstvo, 7(2), p. 35-48.

JOHANSON, Katya and GLOW, Hilary (2012). "It's not enough for the work of art to be great": Children and Young People as Museum Visitors. In: Journal of Audience and Reception Studies, 9(1), p. 26-42.

KANHADILOK, Peeranut and WATTS, Mike (2014). Adult play-learning: Observing informal family education at a science museum, In: Studies in the Education of Adults, 46(1), p. 23-41.

KARADENIZ, Ceren. (2010). Children's museums and necessity for children's museums in Turkey. In: Procedia Social and Behavioral Sciences, 2, p. 600-608.

KELLY, Lynda. (2002). Play, wonder and learning: Museums and the preschool audience. Australian Research in Early Childhood Education 10th Annual Conference, Canberra, Australia. 
KROPF, Marcia Brumit. (1989). The family museum experience: A review of the literature. In: Journal of Museum Education, 14(2), p. 5-8.

KULIK, Taylor Kelsey and FLETCHER, Tina Sue. (2016). Considering the Museum Experience of Children with Autism. In: Curator: The muesum journal, 59(1), p. 27-38.

LANGA, Lesley, A., MONACO, Pino, SUBRAMANIAM, Mega, JAEGER, Paul T., SHANAHAN, Katie, and ZIERBARTH, Beth. (2013). Improving the museum experiences of children with autism spectrum disorders and their families: An exploratory examination of their motivations and needs and using web-based resources to meet them. In: Curator: The Museum Journal, 56(3), p. 323-335.

MAHER, Jill K., CLARK, John and MOTLEY, Darlene Gambill. (2011). Measuring Museum Service Quality in Relationship to Visitor Membership: The Case of a Children's Museum. In: Marketing Management, 13(2), p. 29-42.

MCMANUS, Paulette M. (1987). It's the company you keep: The social determination of learning-related behaviour in a science museum. In: International Journal of Museum Management and Curatorship, 6, p. 263-270.

MEHMETOGLU, Mehmet and ENGEN, Marit. (2011). Pine and Gilmore's concept of experience economy and its dimensions: an empirical examination in tourism. In: Journal of Quality Assurance in Hospitality \& Tourism, 12(4) p. 237-255.

MELTON, Karen K. (2017). Family Activity Model: Crossroads of Activity Environment and Family Interactions. In: Family Leisure, Leisure Sciences, 39(5) p. 457-473.

MINTEL (2004). Family Holidays, Leisure Intelligence. London: Mintel International Group

MITEV, Ariel. (2012). Grounded theory, a kvalitatív kutatás klasszikus mérföldköve. [Grounded theory, a classic milestone in qualitative research]. In: Vezetéstudomány, 43(1), p. 17-30. [In Hungarian]

PINE B. Joseph and GILMORE, James H. (1998). Welcome to the experience economy. In: Harvard Business Review, 76, p. 97-105.

PISCITELLI, Barbara and ANDERSON, David (2001). Young children's Perspectives of Museum Settings and Experiences. In: Museum Management and Curatorship, 19(3), p. 269-282.

POP, Izabela Luiza and BORZA, Anca. (2016). Factors Influencing Museum Sustainability and Indicators for Museum Sustainability Measurement. In: Sustainability, 8, p. 101-123.

POVIS, Kaleen Tison and CROWLEY, Kevin (2015). Family learning in object-based museums: The role of joint attention. In: Visitor Studies, 18(2), p. 168-182.

SANFORD, Camellia W. (2010). Evaluating family interactions to inform exhibit design: Comparing three different learning behaviors in a museum setting. In: Visitor Studies, 13(1), p. 6789.

SCHÄNZEL, Heike A. and SMITH, Karen A. (2014). The Socialization of Families Away from Home: Group Dynamics and Family Functioning on Holiday. In: An Interdisciplinary Journal, 36(2), p. 126-143.

SHINE, Stephanie and ACOSTA, Teresa Y. (2000). Parent-child social play in a children's museum. In: Family Relations, 49, p. 45-52.

SHUANG, Tiffany and LEE, Ching. (2020). Getty Museum Family Room - Educational Issues on Scaffolding and Transfer of Learning. In: International Journal of Art \& Design Education. Early View

SILVERMAN, Lois H. (1989). Johnny Showed Us the Butterflies. In: Marriage \& Family Review, 13(3-4), p. 131-150 
K. Ásványi - Zs. Fehér - M. Jászberényi: The Family-Friendly Museum: Museums through the eyes of families

STERRY, Pat. (2004). An insight into the dynamics of family group visitors to cultural tourism destinations: Initiating the research agenda. New Zealand Tourism and Hospitality Research Conference 2004, Victoria University of Wellington. p. 399-406.

STRAUSS, Anselm and CORBIN, Juliet. 1990. Basics of Qualitative Research: Grounded Theory Procedures and Techniques. Newbury Park: Sage.

SWARTZ, Mallary I. and CROWLEY, Kevin. (2004). Parent Beliefs about Teaching and Learning in a Children's Museum. In: Visitor Studies, 7(2), p. 4-16.

TRINH, Thu Thi and RYAN, Chris. (2013). Museums, exhibits and visitor satisfaction: A study of the Cham Museum, Danang, Vietnam. In: Journal of Tourism and Cultural Change, 11(4), p. 239-263.

VILLA, Lindy. (2006). Rediscovering Discovery Rooms: Creating and improving family-friendly interactive exhibition spaces in traditional museums. Dissertation for Master of Arts. John F. Kennedy University,School of Education and Liberal Arts. 